\title{
CARTOON ANIMALS VS. ACTUAL RUSSIANS
}

\section{RUSSIAN TELEVISION AND THE DYNAMICS OF GLOBAL CULTURAL EXCHANGE}

\author{
Jeffrey Brassard \\ University of Alberta \\ jrbrassard@ualberta.ca
}

\begin{abstract}
Despite continual improvements in production and writing quality, live-action Russian series have fared poorly in the global market. While many deals have been struck, Western remakes of Russian series have failed to appear, and live-action programs have failed to find mainstream audiences outside of Russia. Russian animated series, on the other hand, have enjoyed global success. The success and failure of different types of Russian series in the global media market suggests that many of the central problems of cultural exchange remain. Issues related to cost and risk continue to impede the global transfer of live-action series and formats from Russia even as animated series have become the most widely viewed Russian media products in history.
\end{abstract}

Keywords: Russian television, Russian animation, Netflix, YouTube, global television

\section{Introduction}

Since approximately 2013, Russian television channels and production companies have been racing to sell their products in the global marketplace. Russian companies backed by significant support from the Russian state have taken their products to trade fairs such as MIPTV and MIPCOM and aggressively marketed them globally. Under the brand 'Made in Russia', the Russian state export company Expocontent, an arm of the state firm Russian Export Center, has aggressively marketed Russian content at international media events and hosted events like the Roskontent trade fair. In an editorial for Drama Quarterly, director-general of Expocontent Alexandra Modestova noted that "The global market has started to open up to Russian drama... top Russian producers now focus on the global market and make series intended for worldwide audiences." ${ }^{1}$ Alexander Tsekalo, a former pop singer and owner of Sreda, one of Russia's most innovative production companies, noted in an interview with Russia Beyond the Headlines that "There was a wave of global popularity of Scandinavian TV series, which continues still. Then there was a wave of Israeli TV series, which too is continuing. A similar wave is about to start in Russia."2 Attracting buyers for Russian television series has clearly become a priority for Russian media companies. With Russia now nearly a decade into its experiment in marketing its television products to the global market, it is possible to examine which type of television products from Russia have succeeded and failed and theorize why this has occurred. 
This foray into the global television marketplace has occurred at roughly the same moment that increased competition between broadcast, cable, and streaming video on demand (SVOD) has increased global demand for programs and formats. ${ }^{3}$ As platforms and channels have proliferated, media companies are increasingly competing for audiences. As a result channels and platforms increasingly compete to acquire the right to television programs, they have been going around the globe purchasing the rights to scripted series and formats. The list of programs purchased and localized are well known and do not need to be repeated at length, but it includes such prominent examples as The Office (2005-2013), Homeland (2011-2020), Ugly Betty (2006-2010), House of Cards (2013-2018), and many others. However, as Timothy Havens argues, television has always been a local medium with audiences, particularly in the West's affluent markets, giving precedence to domestically produced programs. ${ }^{4}$ The aggressiveness of SVOD companies like Netflix in acquiring programs poses a new challenge to the local focus that television has long maintained. Netflix, in particular, has aggressively purchased series from countries as culturally distinct from AngloAmerica as South Korea and Russia. The question then arises whether the economics of cultural exchange has been fundamentally altered by the increasing availability of television programs worldwide or whether the cultural dynamics that have favored unscripted formats and animation over scripted formats continue.

Russian television offers an interesting case study for exploring this question for several reasons. Since the end of the Cold War, Russia's television infrastructure has developed rapidly. Though at the end of the Soviet period, Russian television producers could not compete with Western and Latin American products, both Russian and international production companies' significant investments meant that by the early 2010s, Russia had developed a robust television infrastructure. ${ }^{5}$ Today the country boasts six main broadcast networks, dozens of smaller channels, and numerous homegrown SVOD services. Russian production companies and channels offer various programs ranging from animated and live-action programs for children to adult comedies and dramas. There has been an explicit effort on the part of most Russian media companies to increase the visual quality of their offerings. This focus has led to greater investments in equipment and technique to bring the productions up to international standards, including the extensive use of computer graphics to enhance the series. Scriptwriting has also undergone a significant transformation. Today, scripts in live-action Russian television more frequently fall into the category of 'Complex TV,' as articulated by Jason Mittell. The series commonly mix genres and employ either centrifugal narratives, with vast plots and casts meant to draw views into a complex web of relationships, or centripetal narratives that focus on psychological character dynamics and are meant to draw viewers into the story. ${ }^{6}$ Most are at least on par with television series from the West in terms of visual quality. Russian companies provide the major networks in Russia with most of their scripted prime-time content. Consequently, Russian companies have a range of programs to offer the international television market. Today Russia is exporting three main programming types: finished live-action series, formats, and animated series primarily aimed at preschool children. While the live-action series have seen limited success, Russia's animated series for children have been a wild success. The example of Russia's television industry suggests that many of the cultural factors that have limited the flow of media texts between regions continue to limit Russian media's growth in the global market. Products like animation that can be stripped of their culturally specific markers are still more likely to succeed in the global television marketplace than their live-action counterparts that stubbornly retain elements of their culture of origin. Programs from countries that are not Western and therefore on the margins of global culture succeed in the global television marketplace when they present few cultural markers and ultimately have relatively simple plots and stories that translate well. As a result, television aimed at children and preschoolers has a much greater chance of succeeding globally. The case of Russian television also points to the relative advantage of animation in comparison to scripted formats. Animation can be sold as a packaged format which only needs to be voiced into a local language, while live-action programs typically need to be turned into a format and remade. Particularly in the large Western markets, programs with voiceovers or subtitles are unlikely to be very successful. ${ }^{7}$

\section{Theoretical Considerations}

There are three key concepts to consider when examining the challenges faced by television programs attempting to move outside their cultural zones. The first of these is what Joseph Straubhaar calls "cultural proximity." The term 
cultural proximity is used by Straubhaar to denote aspects of culture like "humor, gender, images, dress, lifestyle, knowledge about other lifestyles, ethnic types, religion, and values." ${ }^{\prime 8}$ By this, he means that people prefer to consume media from a culture similar to their own. ${ }^{9}$ This concept means that Russian cultural products would only be successful in the countries with which it shares cultural ties since audiences from other societies are likely to find elements of Russian culture, such as lifestyle and gender norms off-putting. In contrast, given its relative ubiquity globally, Western and particularly British and American media texts suffer less from issues of cultural proximity. Their omnipresence in cinema, popular music, and television means people always expect Western culture to be present. Straubhaar's concept is similar to Hoskins and Mirus' idea of the "cultural discount," which essentially suggests that the more tenuous the links between two cultures, the more difficult it will be for cultural texts to move from one to the other. ${ }^{10}$ Once again, American and Western texts do not suffer cultural discount because they are standards against which other texts are measured. Together these two concepts suggest that it is challenging for a media text from a culturally peripheral country like Russia to gain full acceptance outside of its region, except in places that share a degree of cultural similarity and shared history. Hoskins and Mirus argue that it is the problem of "cultural discount" that has allowed American culture its dominance, as it has become the universal cultural grammar of the majority of the world through its omnipresence. By virtue of its powerful appeal, marketing, and distribution, American culture can easily enter other cultures. However, people in Anglosphere countries rarely accept cultural products from outside their cultural zone. Programs that have gone from one region to another as formats have often been from regions that share a degree of cultural proximity with Anglo-America. As Oren and Shahaf note, the waves of format adaptations that brought programs like The Bridge (2011-2018) and The Killing (2011-2014) from Scandinavia and programs like Homeland (2011-2020) and In Treatment (2008-2010) from Israel to the United States were still from countries that share broad cultural links to English-speaking countries. ${ }^{11}$

Formats have proliferated in the last thirty years as producers in many countries have tried to find ways of minimizing risks and costs while still drawing significant audiences. Formats, particularly in their unscripted iterations, have proven ideal in this regard. They also provide access to proven content that can be easily localized. Jean Chalaby suggests that formats are a way for television producers to integrate the success of global television products into their local markets while at the same time making the global origins of these programs essentially invisible. He argues that "the rules of a format are put in place to weave narratives and disappear behind the stories they generate... formats may be international to the industry, but they are always local to the audience."12 The ultimate goal of formats is to make the origins of a program as invisible as possible by making the content appear local. The process of adapting a program is, however, expensive and often complicated. Chalaby notes that "the entire premise of the TV format trade hinges on two benefits: cost-effectiveness and risk management."13 However, scripted formats are at a disadvantage since "any scripted adaptation must go beyond copycat television and re-actualize the script for a new audience."14 Moran suggests that format localization "entails erasing cultural signs that establish cultural distance between programs and audiences, and instead developing markers that signal common belonging." 15 To do that essentially requires remaking the program in its entirety. This type of remake's relative costs are high, which presents a problem, especially in high-cost markets like the United States. Chalaby notes that in addition to cost, "scripted formats do not afford risk-management levels comparable to those offered by unscripted ones. In fact, US networks' worst-performing series of autumn 2013 was a remake of The Syndicates that saw ABC experience a fifty-five per cent ratings drop between Lucky 7 and the show it replaced." ${ }^{16}$ Consequently, American media firms remain cautious about investing resources into formats, particularly from culturally marginal nations.

The proliferation of prominent scripted formats in the past three decades might suggest that the global television marketplace is overcoming cultural discount. However, Moran and Keane have been critical of how the format market has developed, noting that it has reproduced already existing power structures in global media markets in many ways. Specifically, they suggest that most of the creators and rights holders of large successful formats were from either the United States or the European Union, with a few Latin American formats. ${ }^{17}$ Since their work was published, there have been notable sales of formats from outside the "core" Western markets. However, as of 2021, the most successful format companies remain entirely based in France, the Netherlands, the United Kingdom, or the United States. Other nations have occasionally had limited success, such as ABC The Good Doctor (2017-) adapted from a South Korean program Gut Dakteo (2013). However, the industry's core remains in the West and its proxies, such as Israel. Chalaby also notes that since the beginning of the format trade, "US broadcasters have aired 119 scripted format adaptations, 
most of them originating from the UK." ${ }^{18}$ This fact suggests continued resistance in the largest market in the world to products from outside the Anglosphere.

Animated programs have also been competing for global market share but differ significantly from formats in their approach and in their success. One of the principal differences is that most of these programs are aimed at children. The other is that even when they are transferred from one market to another, they do not require the same degree of adaptation as other texts. In his study of the Pokémon phenomenon, Koichi Iwabuchi identified techniques in the Japanese animation industry that circumvent some of the challenges television series have when moving from one region to another. He notes that television series often have many cultural markers that indicate their culture of origin, which he terms their 'cultural odor.'19 He defines 'cultural odor' as the elements that tie a cultural product "with widely disseminated symbolic images of the country of origin," often in a way that can be disconcerting to global audiences. ${ }^{20}$ These markers are specific to culturally peripheral countries, especially those that are non-western. Because of its ubiquity, Western culture's cultural odor is accepted in most places. Consequently, Western cultural odor does not result in a 'cultural discount.' Iwabuchi suggests that Japanese animators have long created cultural texts that are easily exported by ensuring that cultural markers that would signal the series as Japanese are removed. ${ }^{21}$ To avoid being too rigidly tied to their homeland's culture and, therefore, unacceptable to global audiences, Japanese animators often draw characters that do not look Japanese, a style they call mukokuseki. ${ }^{22}$ Consequently, to move the text from one market to another simply requires removing any text in the language of origin (or not inserting such text in the first place) and replacing the voice track.

Iwabuchi identifies that animation has a distinct advantage when it comes to accessing the global marketplace. It is more easily passed from culture to culture with minimal adaptation. Animation differs significantly from both scripted and unscripted formats. It offers a ready-made visual product that requires only minor adjustment to be globally marketable and products with a strong track record. Pokémon is the most prominent example, though both Disney and Nickelodeon operate channels worldwide that translate animated products into local languages. As a result, animation carries considerably fewer costs and risks than scripted formats.

The degree to which Russian series entering the global media market today can thrive reveals essential information about what kinds of programs succeed in the global market. Much of this will hinge on whether the problem of "cultural odor" continues to hamper certain products from succeeding outside their cultural spheres of origin. The cases of Russian television series that have been sold abroad show that even in the era of an increased number of platforms and channels and an increasing demand for programs, the cultural dynamics that have hampered the flow of cultural products outside of their cultural spheres remain. Scripted live-action programs, which are either subtitled, dubbed, or turned into a format, remain considerably riskier and, therefore, less attractive than their unscripted and animated counterparts.

\section{Methodology}

Methodologically this paper examines the topic of the Russian media trade from the perspective of Critical Media Industry Studies. ${ }^{23}$ This methodology is principally targeted at generating rich accounts of media industries by focusing on the numerous outputs of those industries. In this case, this account is principally focused on texts generated by the Russian media industry trade press, the popular press, and content analysis of individual programs. This article mainly draws on media texts that are highlighted and republished on the Facebook page Russian MIPCLUB. This page, run by the Russian state firm Expocontent, serves as an aggregator for news from various other industry trade publishers for news about the Russian media in the global market.

This article's focus is television since it represents the Russian media industry that is most active and consequently most attractive to foreign buyers. While the Russian film industry's output is improving, Russian films outside of the 
former Soviet Union remain mostly limited to a small selection of art films like the 2014 film Leviathan. While they are increasingly sophisticated in terms of visual style and production techniques, Russian blockbusters are mostly limited to the Russian-speaking market. While there are a few notable exceptions, such as the Disney co-production Poseldniy Bogatir (2018), television offers a much richer avenue for comparison. While unscripted formats are also an essential part of the global exchange in program formats, Russia has yet to produce any that have been marketed globally. As such, while they are acknowledged as important, they are discussed only in passing.

\section{Russian Live-action Series in the Global Marketplace}

Russia's first significant foray into the global format market was Kukhnia (The Kitchen) (2012-2016). The series is a workplace comedy that takes place principally in a French restaurant in Moscow called 'The Claude Monet.' It has spawned two feature films and three spinoffs, making the series one of Russia's most successful media franchises. The series is careful to be as "culturally odorless" as possible for a live-action series. The setting, a high-end French eatery, could be transferred easily to virtually any global city. The series' set designs are mostly generic, as a high-end dining room and an industrial kitchen are typical of many restaurants. Even the non-diegetic music for the series is mainly licensed from English-speaking artists, including Beyoncé, Neon Trees, Enya, OK GO, or classical music. ${ }^{24}$ Since it is a workplace comedy, the humor in the series is principally related to romantic misadventures between the staff, the problems emerging from the head chef's alcoholism and gambling problem, and workplace issues like competing with a neighboring restaurant. In essence, much of the humor resembles that found in contemporary Western workplace comedies like The Office (2005-2013), Brooklyn Nine-Nine (2013-2022), and Superstore (2015-2021).

The efforts to create this culturally odorless program attracted the attention of some global media conglomerates. On November 26, 2013, STS announced that it had reached an agreement with the American network CBS's international distribution arm to license the Kukhnia format outside Russia. ${ }^{25}$ This deal resulted in the creation of four formatted versions of the program in Georgia, Estonia, Greece, and Portugal under the CBS license. CBS has, from all the available evidence, never attempted an American adaptation of the program. Instead, the only place the series has appeared in English has been through a subtitled version available on Amazon's Prime Video. Regardless, the series is a milestone in terms of success as an adaptation and proved to Russian producers it was possible to move into the global market. Following the deal, Russian producers have been eager to make deals.

An unfortunate pattern has been repeated when Russian series are sold as scripted formats in the global market. For example, the horror program Moimi Glazami (Through My Eyes) (2013) was purchased by Fox television in $2015 .{ }^{26}$ Whether the pilot was ever filmed is hard to ascertain, but it appears the series never made it far beyond that stage, if it was made at all. Another series Mazhor (Silver Spoon) (2014 -), was purchased by Netflix and is currently available with English subtitles. A second deal with Sreda, the production company that created Mazhor, led to Netflix licensing most of their catalog, which is also available with subtitles. As part of a separate deal, Sreda discussed licensing the series as a format to an American company, Critical Content, mostly known for its production of reality television programs. ${ }^{27}$ The American version has yet to materialize, though a South Korean adaptation has been announced. ${ }^{28}$ Another workplace comedy, CH.O.P (Private Security Firm) (2015-2016), was purchased as a format by Fox Television. ${ }^{29}$ As of March 2021, it does not appear that Fox picked up the series as it is not in the list of series ordered as pilots, though it may still be in development. ${ }^{30}$ Another program, the Russian action drama Kvect (Quest), was purchased by an American network, NBC, and is theoretically in development. ${ }^{31}$ While these deals are frequently announced, none has ever been produced in a large market.

When looking at relative success on the global stage among major Russian live-action series, the most notable outlier is Luchshe Chem Lyudi (Better Than Us) (2018). 


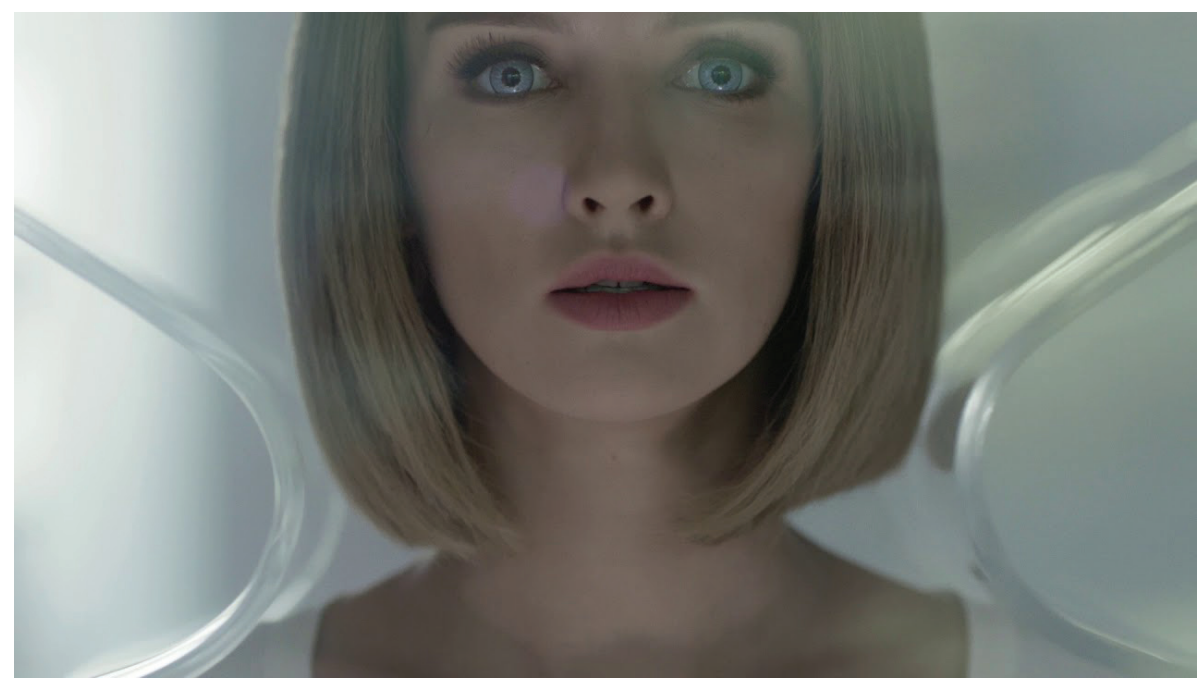

Video 1. Better Than Us, the first Russian series marketed as a Netflix Original Series.

At the beginning of 2019, the series was licensed by Netflix as the first series from Russia to appear under the "Netflix Original" banner. The series was sold to Netflix for the record sum for a Russian series of a million US dollars. ${ }^{32}$ The series follows the exploits of Gregory Safronov (Kirill Karo) and his family in the year 2029 as they navigate a world where realistic androids have become nearly indistinguishable from humans. Mixed into the plot is the story of an anti-technology group called "the liquidators" that object to the replacement of humans by androids and stage a series of violent anti-android protests. Because the series is science fiction and set in the near future, its cultural references are distanced from contemporary Russian culture. The series mainly presents future companies and settings that are not recognizably Russian. Since they are principally from circa 2029, the series' cultural references do not immediately anchor the series in contemporary Russia.

The series generated a considerable amount of attention on the international stage at MIPCOM in Cannes, France. In April 2017, the series was a finalist in the MIPDrama Screenings in the category of "Works in Progress". ${ }^{33}$ Because Netflix does not release ratings data, it is challenging to ascertain how many viewers streamed the series. However, the program was featured prominently on the front pages of Netflix for a few weeks in August of 2019. On August 29, 2019, the production company Yellow, Black, and White posted a message on its Facebook page that read, "We've conquered the continents. Better Than Us is among the most-watched shows on Netflix. Our actors offer their thanks". ${ }^{34}$ Presumably, this suggests that the series did quite well on Netflix.

\section{Russian Animation}

Unlike its live-action cousin, the Russian animation industry's story on the global stage has been one of mass distribution and successful sales. Numerous Russian animated programs air in countries all over the world. Russian producers have produced several programs that have reached a large audience and even one global phenomenon. The difference between live-action and animated programs strongly suggests that the cultural divides that have traditionally kept television texts from flowing from one region to another are still in place. As such, animated products that can carry fewer cultural markers have a better chance of gaining wide adoption.

The first Russian animated series that transitioned to Western screens was Smeshariki (2003-2012). The series was commissioned by the Russian Ministry of Culture, which wanted a series for children that created the image of "a world without violence." ${ }^{35}$ It features stylized rounded animals in playful adventures. Its target audience is five to 
J. Brassard, Cartoon Animals vs. Actual Russians

eight-year-olds. In September of 2008, the studio that produces the series, Peterburg, announced that the series had been purchased by 4 kids Entertainment and would be airing on The CW under the title GoGoRiki. ${ }^{36}$ The American network also purchased the second season of the programs, which aired starting August 22, 2009. Since then, the series has gone on to air in sixty countries and has an audience of approximately fifty million, principally in China. ${ }^{37}$ The series' largest audience is in China, and in 2019 a joint Chinese-Russian venture was formed to create a new spinoff series called Panda and Smeshariki. ${ }^{38}$

Smeshariki, while reasonably successful compared to the live-action series listed above, hardly compares to the next animated series to emerge from Russia, Masha i Medved (Masha and the Bear) (2009-). The series follows a preschool girl named Masha, who lives in the forest, presumably with her parents and pet pig, goat, and dog. Masha is continually getting into trouble, and all the forest animals avoid her because she forces them to play wild games. In the first episode, she sees a butterfly and follows it into a retired circus bear's house while he is away fishing. She destroys the house and earns the bear's ire. While he initially tries to get rid of her, he eventually warms to her and becomes her de facto protector. The series relies primarily on pantomime as the bear, and the other forest animals do not speak. This technique immediately makes the series easy to adapt to other markets. Animaccord Animation Studio has produced eighty-nine episodes of the program, which have been praised for their animation quality. ${ }^{39}$ In 2015 , Masha and the Bear won the award for the best animation from Kidscreen Magazine. It was also listed as one of two-hundred fifty programs "destined to be classics" by Animation Magazine. ${ }^{40}$

The series is almost assuredly the most successful Russian media product in history. As of this writing, an episode of the series titled Masha + Kasha (A Recipe for Destruction) on the YouTube channel Get Movies has garnered over four billion views making it the fourth most viewed video on the platform.

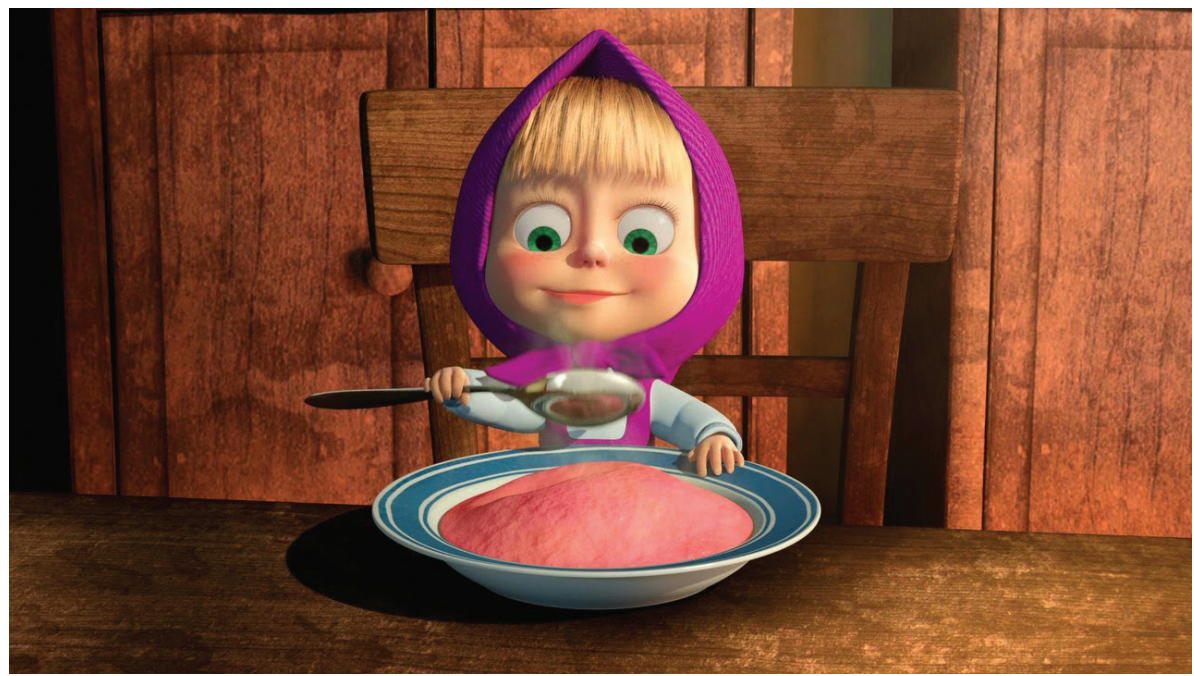

Video 2. Masha+Kasha, the fourth most viewed Youtube video of all time.

This episode is the only non-music video in the top twenty most viewed videos on YouTube and the most-watched animated feature on the video-sharing service. Two other episodes of the series have over a billion views each, and six others have over three hundred million. The series' YouTube channel is in the top twenty most-viewed worldwide and earns the company one and a half million dollars each month in ad revenue from the platform and has nearly thirty million subscribers. ${ }^{41}$ Adding to this success, in August of 2016, Animaccord signed a deal with Netflix, which brought the series to the SVOD platform. Clearly, the series has a robust online presence, one much greater than any other Russian media product. The series also airs in a hundred and fifty countries worldwide either on SVOD platforms or on traditional broadcast and was translated into thirty-nine languages. ${ }^{42}$ During the 2020 Covid-19 pandemic, the international media ratings agency, Parrot Analytics, reported that the series was the fourth most-viewed children's program in the world at the peak of lockdowns. ${ }^{43}$ 
J. Brassard, Cartoon Animals vs. Actual Russians

Masha and the Bear's revenue generated from YouTube and other deals to broadcast the series represent a triumph for the Russian industry. These are, however, not the only sources of revenue for the producers. Animaccord also has signed numerous licensing deals that have allowed it to produce and sell licensed merchandise. Driven by the success and wide distribution of the series online and through broadcast, the series has grown into one of the world's most valuable licensed brands. According to a Forbes report in 2019, Animaccord rose four places to ninety-first place on License Global's list of the top hundred-fifty licensed brands by revenue. The company, whose licensing revenue was listed at three-hundred-twenty-nine million US dollars, rated ahead of venerable brands like Sketchers USA, John Deere, and Crayola and slightly behind CBS, Activision Blizzard, and Sony Pictures Entertainment. ${ }^{44}$ This accomplishment is remarkable for a Russian company that only began producing Masha and the Bear in 2009. Licensed products from the programs are available widely in many of the markets in which the series airs.

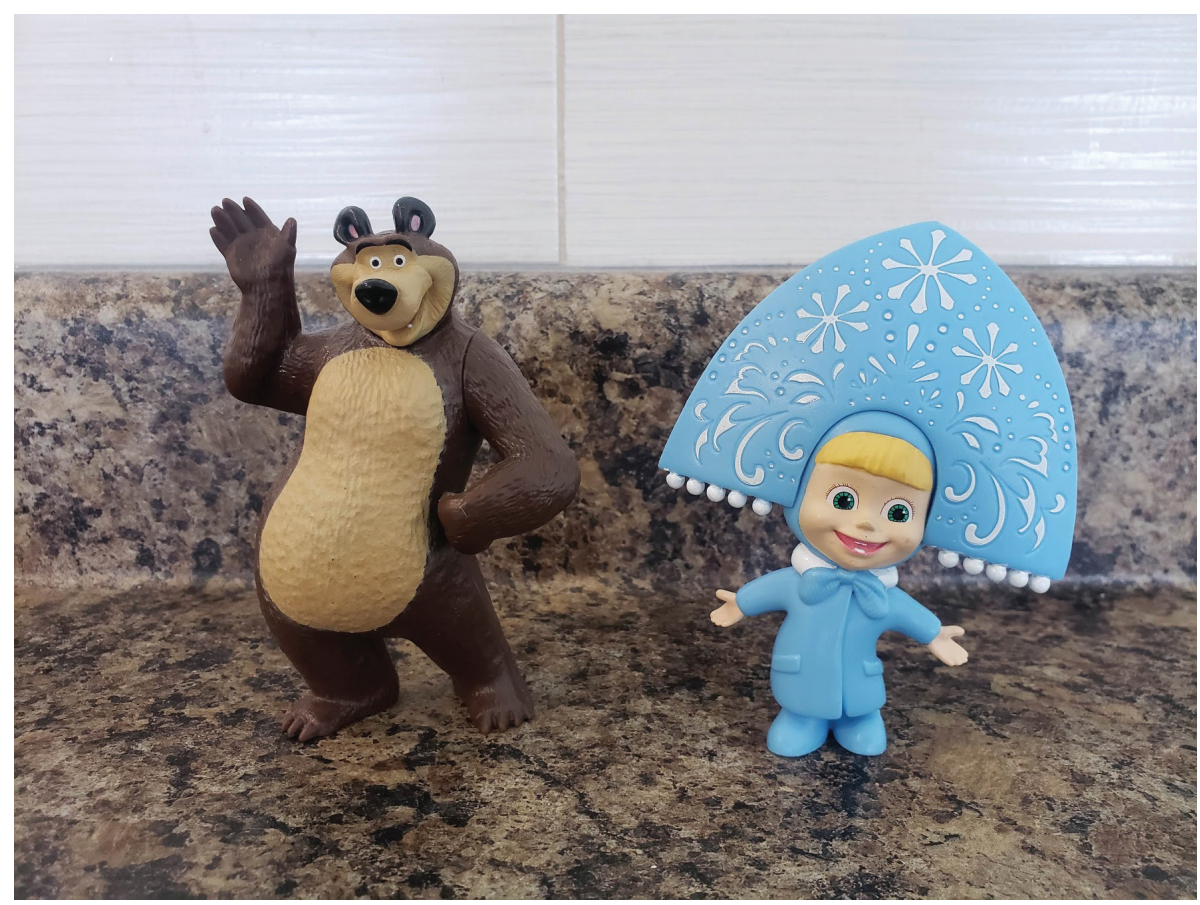

Figure 1. Masha and the Bear figurines purchase at a bookstore in Edmonton, Canada.

This revenue stream will likely continue to increase in the next few years since the series began airing in China and Japan in early 2020, and Animaccord signed a deal to sell licensed products based on the series in China in May 2020. Given the vastness of the Asian market, it seems likely that licensing revenue will continue to rise.

The success of Masha and the Bear is extraordinary by almost any standard. The success of the series has also opened a vast market for Russian animation. Following the success of the Animaccord series, other Russian animated programs have attracted international distributors' attention. The most successful of these has been Tri Kota (2015-), marketed internationally as Kid-E-Cats. The series, produced by STS Kids and British distributor APC Kids, currently airs in a hundred-forty-three countries worldwide, principally through a deal with the network of international stations under the "Nick Jr" banner. Netflix acquired other series like Leo $i$ Tig (Leo and Tig) about a pair of adventurous leopard and tiger cubs and Mi-mi-mishki (Be-Be Bears) in its push for more family-friendly content. ${ }^{45}$ Since the rise of Masha and the Bear, Russian animation's potential in the marketplace has garnered considerable international attention. At the 2019 MIPJunior trade fair in Cannes, France, the Russian industry took center stage in an event titled "Made in Russia: The Next Animation Boom," which allowed many Russian animation studios to market their programs to international buyers. ${ }^{46}$ The Russian animation industry's recent importance suggests that it is well regarded, and an overall expectation that its programs will perform well on the global stage. 


\section{Discussion}

Russian animation is enjoying an unprecedented boom period and a great deal of interest from global buyers. To this point, Russian animation has principally been offering content exclusively tailored to younger children. This part of the Russian television industry's success is notable, particularly compared to Russian media products' rather anemic presence in the live-action space. This dichotomy does present some analytical issues. The principal one is that the two categories are not aimed at the same audience. The live-action programs Russia has tried to export are principally intended for viewers aged fourteen to fifty, while its animated products are principally targeted at preschoolers. The fact that it is targeted at children plays a vital role in the success of animation. Thematically the texts are relatively simple and do not bring in significant cultural markers. For example, a typical episode of Masha and the Bear features the precocious girl getting into trouble that needs to be resolved by the Bear or somehow causing difficulties for him. In the most famous episode Masha + Kasha, the Bear leaves Masha alone in his house to finish recreating a scene from a famous checkers game. Because she is hungry, she decides to make herself some porridge. As a child might do, she pours box after box of porridge into a pot, and it soon starts pouring out of the pot. She tries to resolve the situation by pouring it into every available container and feeding it to any animal she can find. The scenario ends with the Bear's home full of porridge. Together they clean his home and return everything to its original state. While the episode is genuinely charming, it relies primarily on pantomime, which is a universal language.

Other animated products take different strategies but also have simple plots. The first episode of Kid-E-Cats, for example, follows the three main characters as they try to buy a present for their father's birthday. They dream of buying him a bicycle, a helicopter, and a spaceship but are ultimately convinced by their mother to buy him a singing birthday card. Once purchased, they listen to it so many times that they drain the battery. After attempting to coax more music out of the card, which ends in its accidental destruction, they ultimately decide to make their own card. Again, this plot is simple and relatively universal to the experiences of children. While the various Russian animation genres offer different scenarios and stories, they all fall into these easily understandable molds. Ultimately, by targeting young children, Russian animators can create straightforward stories that are easily understandable and accessible. These stories cross-cultural boundaries relatively quickly. After all, many children have had a kitchen disaster or tried to find the perfect gift for a parent. These simple scenarios are easily dubbed in many languages with little work, and as a result, the texts travel easily.

Even the elements of Russian animated texts that do not travel well or that are culturally specific do not seem to pose very many difficulties. For example, in the episode of Masha and the Bear titled 1, 2, 3 Yolichka Gori (1, 2, 3 Light the Christmas Tree), Masha accidentally injures Santa, which results in the bear having to take his place. Masha is then dressed by the Russian Santa Claus as the traditional Russian folk character Snegourichka (Snow Maiden) and is tasked with helping the bear deliver gifts. While immediately recognizable to Russians, these cultural markers do not detract from the episode itself. Regardless of the culture, because so much of Masha and the Bear relies on pantomime, it is mostly self-explanatory. This simplicity probably explains why the show has accumulated many views on YouTube, despite the episodes still being voiced in Russian. Even if someone does not speak Russian, they can still understand the series' charm and humor. This accessibility is the reason the program does not suffer from the problem of cultural discount.

Russian live-action series are aimed at adults and consequently do not enjoy the type of cultural leeway given to animated series. Series such as Better Than Us (2018-2019) and Silver Spoon (2014-) that are shown with the original Russian dialogue on streaming services such as Netflix are bound to attract only a small audience following because they remain principally inaccessible to most audiences. While they are available, watching many hours of subtitled television requires a great deal of concentration. Understanding the cultural context of Russia also requires some effort from audiences. For example, Igor, the protagonist of Silver Spoon, is the son of a Russian Oligarch, a group of very powerful businessmen who acquired their wealth through connections with the state during the Yeltsin era. The fact that his father was able to pay for him to be attached to a squad of detectives is a particularity of Russian 
society that might be difficult for non-Russians to understand. The Russian police force's structure also presents a particular problem as the ranks and units are distinctly Russian. Regardless, the fact that these series are simply subtitled means that they are unlikely to find anything more than a niche audience. Adaptations of formats offer a much greater possible audience but face significant challenges.

The fact that no Russian series have yet gone from format to full-fledged adaptation in the West's highly desirable markets suggests that the market economics governing scripted format production still work against Russian content being adopted. While occasionally deals may be made for a few Russian series, these markets will continue to prefer scripted products from countries whose products suffer from less cultural discount than Russia. Scripted formats remain far riskier than unscripted formats and animation. While much has been made of the increased trade in scripted formats, the Russian experience suggests that with a few outliers, scripted formats from nations outside the West that succeed, particularly in the American market, are likely to remain relatively few in number.

\section{Conclusion}

The Russian television industry's experience as it has entered the global market reveals that while there has been a proliferation of television channels and platforms all looking for appealing content with a record of success, the traditional challenges that televisual products face in transitioning from cultural sphere to another remain. Despite improvements in the quality of its television series at the level of production values and in the quality of script, formats from culturally distant countries like Russia represent too significant a risk for producers in the large Western markets to bring them to the screen. The returns for Russian companies are also modest when compared with the possible profits from animation. To put it into context, the most considerable sum for a Russian live-action series was the million dollars that Netflix paid for Better Than Us in 2019. The YouTube channels associated with Masha and the Bear generate that much revenue in two months. The focus given by Expocontent (the Russian cultural export firm) to Russian animation underscores that animation is a much better market for Russian producers. While Russian companies continue to market their programs as formats, subtitled, or dubbed programs, the Russian animation industry was given its own section under the heading "Made in Russia" at the 2019 MIPCOM trade show by a Russian state agency. The implication for producers from nations that are not culturally proximate and consequently suffer from a cultural discount is obvious. Scripted program formats are far less likely to succeed in the global market than animated programs or unscripted formats. To the extent that capacity exists, those avenues are far more fruitful than risking the remote chance that a series made in Russia or elsewhere might be the next The Good Doctor (2017-), Ugly Betty (2006-2010), or Jane the Virgin (2014-2019).

\section{Notes}

1. Alexandra Modestova, "Steppe Change," Drama Quarterly, February 5, 2019, https://dramaquarterly.com/steppe-change/

2. "How Alexander Tsekalo and Russian TV Series Conquered Netflix and the World," Russia Beyond the Headlines, May 10, 2017, https://www.rbth.com/arts/2017/05/10/how-alexander-tsekalo-and-russian-tv-series-conquered-netflix-and-theworld_759916

3. Jean K. Chalaby, "Understanding Media Globalization: Global Value Chain Analysis," in The Routledge Companion to Global Television, ed. Shawn Shimpach (New York: Routledge, 2019), 375.

4. Timothy Havens, "What Was Television?: The Global and the Local," in The Routledge Companion to Global Television, ed. Shawn Shimpach (New York: Routledge, 2019), 30.

5. Jeffrey Brassard, "Russian Sitcoms: From Post-Soviet Copycats to Aspiring Global Players," Palabra Clave 20, no. 3 (2017), http://palabraclave.unisabana.edu.co/index.php/palabraclave/article/view/7239

6. Jason Mittell, "Narrative Complexity in Contemporary American Television," The Velvet Light Trap 58, no. 1 (2006): $29-40$.

7. Tessa Dwyer, Speaking in Subtitles: Revaluing Screen Translation (Edinburgh: Edinburgh University Press, 2017$), 2$. 
8. Joseph Straubhaar, "Choosing National TV: Cultural Capital, Language, and Cultural Proximity in Brazil: A Paradigm Shift," in The Impact of International Television, ed. Michael G. Elasmar (London: Routledge, 2003), 77-78.

9. Joe Straubhaar, "Global, Regional, Transnational, Translocal," Media Industries 1, no. 3 (2015): 48-53.

10. Colin Hoskins and Rolf Mirus, "Reasons for the US Dominance of the International Trade in Television Programmes," Media, Culture \& Society 10, no. 4 (1988): 499-515.

11. Tasha Oren and Sharon Shahaf, "Introduction," in Global Television Formats: Understanding Television Across Borders, ed. Sharon Shahaf and Tasha Oren (New York: Routledge, 2013), 1-20.

12. Jean Chalaby, "Reflection i: Transnational TV Formats: Making the Local Visible and the Global Invisible," Critical Studies in Television: The International Journal of Television Studies 8, no. 2 (2013): 55.

13. Timothy Havens, Amanda D. Lotz, and Serra Tinic, "Critical Media Industry Studies: A Research Approach," Communication, Culture \& Critique 2, no. 2 (2009): 234-253.

14. Jean K. Chalaby, The Format Age: Television's Entertainment Revolution (Cambridge and Malden, MA: Polity Press, 2016), 157.

15. Albert Moran, ed., TV Formats Worldwide: Localizing Global Programs (New York: Intellect, 2010$), 65$.

16. Chalaby, The Format Age, 160.

17. Michael Keane and Albert Moran, "Television's New Engines," Television \& New Media 9, no. 2 (2008): 155-169.

18. Chalaby, The Format Age, 160.

19. Koichi Iwabuchi, Recentering Globalization: Popular Culture and Japanese Transnationalism (Durham: Duke University Press, 2002), 36

20. Ibid., 38.

21. Koichi Iwabuchi, "How 'Japanese' Is Pokemon," in Pikachu's Global Adventure: The Rise and Fall of Pokémon, ed. Joseph Jay Tobin (Durham: Duke University Press, 2004), 58.

22. Ibid., 58.

23. Havens, Lotz, and Tinic, "Critical Media Industry Studies."

24. Brassard, "Russian Sitcoms."

25. Katerina Kitayeva, "Russkaya Kukhnya Dlya Amerikantsev" [Russia's The Kitchen for Americans], RBC, November 26, 2013, http://rbcdaily.ru/media/562949989726542

26. "Kanal Fox Peresnimet Serial TNT" [Fox Remakes TNT Series], Lenta, March 12, 2015, https://lenta.ru/news/2015/12/03/ through_my_eyes/

27. Svetlana Povoraznyuk, “Chernokozhiy Druz' i «Papiny Dochki» Po-Nemetski” [Black Friends and 'Daddy's Girl's' in German], Lenta, January 26, 2017, https://lenta.ru/articles/2017/01/26/tvexport/

28. S Park, “Popular Russian TV Series 'Silver Spoon' To Be Remade In Korea,” Soompi, June 18, 2019, https://www.soompi. com/article/1333077wpp/popular-russian-tv-series-silver-spoon-to-be-remade-in-korea

29. Vladimir Kozlov, "Fox Set to Adapt Russian TV Series 'Building Security'," The Hollywood Reporter, November 7, 2019, https://www.hollywoodreporter.com/news/fox-set-adapt-russian-comedy-series-building-security-1253388

30. Erik Pedersen, "2020 Fox Pilots \& Series Orders," Deadline (blog), January 11, 2020, https://deadline.com/pilot/2020-foxpilots-series-order/

31. Nellie Andreeva, "Action Drama 'Escape' Based on Russian Format In Works At NBC From 'Lucifer' EP \& Intrigue,” Deadline (blog), November 22, 2019, https://deadline.com/2019/11/escape-action-drama-russian-format-nbc-jason-ningintrigue-1202793113/

32. Anna Afanaseeva, "Rossiyskiye Prodyusery Zagruzili Netflix" [Russian Producers Conquer Netflix], Kommersant, November 1, 2019, https://www.kommersant.ru/doc/3850558

33. Editorial Board of The Hollywood Reported Russian Edition, “«Trotskiy», "Gogol'» i Tsekalo Yedut Pokoryat' Kanny” ['Trotsky,' 'Gogol,' and Tsekalo Go Conquor Cannes], The Hollywood Reporter: Russian Edition, May 10, 2017, http://thr.ru/tv/trockijgogol-i-cekalo-edut-pokorat-kanny/

34. "Better than Us," accessed May 22, 2020.

35. Argumenti i Fakti, "'Smeshariki': Sekrety Sozdaniya Geroyev” ['Smeshariki': The Secrets of Creating Heroes], Argumenti $i$ Fakti, June 26, 2009, https://aif.ru/onlineconf/1392113

36. “4KIDS Entertainment Unveils '08-'09 Saturday Morning Lineups for FOX and The CW Television Networks: Financial News Yahoo! Finance," Yahoo News, January 4, 2009, https://web.archive.org/web/20090104211358/http://biz.yahoo.com/ iw/080903/0429959.html

37. Egor Movshchikov, "Smeshariki Po-Pekinski" [Smeshariki in Peking], Russkii Reporter, April 15, 2014, http://rusrep.ru/ article/2014/04/15/smeshariki-po-pekinski

38. "Mul'tiplikatory RF i KNR zaklyuchili v Pekine dva soglasheniya o sotrudnichestve" [Companies from the Russian Federation and China conclude two cooperation agreements in Beijing], RIA Novosti, May 15, 2019, https://ria.ru/20190515/1553513933. html

39. Nadezhda Ustinova, "How Russian Animation 'Masha and the Bear' Won the Hearts of the World," Russia Beyond the Headlines, https://rbth.com/longreads/masha_and_bear 
40. The Associated Press, “Masha and the Bear': Russian Cartoon Takes the World by Storm," Syracuse, April 12, 2016, https:// www.syracuse.com/tv/2016/04/masha_and_the_bear_russian_cartoon_popular_world.html

41. Ibid.

42. "Mul'tfil'm 'Masha i Medved" za karantin voshel v top-5 detskikh shou v mire" [Cartoon 'Masha and the Bear' ranks in the top 5 children's show during quarantine], RIA Novosti, May 25, 2020, https://ria.ru/20200525/1571974614.html

43. Ibid.

44. Rinat Tairov, "Sozdateli «Mashi i medvedya» podnyalis' v reytinge krupneyshikh mirovykh litsenziarov" [The creators of 'Masha and the Bear' rise in the rankings of the world's largest licensors], Forbes Russia, August 8, 2019, https://www.forbes.ru/ biznes/381533-sozdateli-mashi-i-medvedya-podnyalis-v-reytinge-krupneyshih-mirovyh-licenziarov

45. Sara Aridi, "Netflix Acquires Worldwide Rights for Two Russian Cartoons," The New York Times, September 15, 2018, https:// www.nytimes.com/2018/09/15/arts/television/netflix-acquires-worldwide-rights-for-two-russian-cartoons.html

46. Elena Trusova, "Rossiyskaya animatsiya v tsentre vnimaniya na MIPJunior" [Russian animation in Spotlight at MIPJunior], Proficinema, October 14, 2019, https://www.proficinema.ru/mainnews/markets/detail.php?ID=286590\&fbclid=IwAR1ngM 1pBGRF0xZ06TtnZTnsKXs5pQ0VUqkxD22PYH5vyYBKi4-3c5SPxQ0

\section{B i o graph y}

Jeffrey Brassard is an Assistant Instructor and Administrative Coordinator of the Center for Criminology Research in the Department of Sociology, University of Alberta. He is the author of articles in the Journal of Popular Film and Television, Palabra Clave, The Journal of Historical Fiction, VIEW: Journal of European Television History and Culture and Media Industries Journal. 